\title{
NORTHERN RHODESIA
}

From the 1951 Report of the Game and Tsetse Control Department The Kafue National Park.

For map and description see Oryx, Vol. I, No. 1.

Progress in the development of the Park is very satisfactory. The quantity and tameness of the animals in the southern section justifies the decision to open this section to the public, with limited facilities, for the 1953 Rhodes Centenary Exhibition. Numbers of all the local species of antelope, with buffalo and zebra, were seen without difficulty from July onwards till the rains broke. The game is definitely responding to the care taken for its preservation.

The larger carnivores were greatly in evidence during the season, possibly due to the general scarcity of water in the surrounding country after the patchy rains, though the Park itself did not suffer in this respect, but also no doubt owing to the steady drift of game to the sanctuary of the Park. The question of balance between carnivores and the ungulates on which they prey comes into issue : this is all the more important if, as may be the case, the sanctuary conditions in a Park in fact reflect a change in the normal balance, the virtual taming of the animals presenting conditions which start off trouble.

Wild dogs were seen in great numbers: these animals are undesirable in large packs as over a period of days they will completely denude an area of game, and the situation will be watched, so that control measures may be applied when necessary.

\section{Game Reserves.}

Three new Game Reserves were declared during the year :-

Fort Rosebery (750 square miles) : an uninhabited area for general preservation of the fauna, lying roughly between the Luera river and the old Kapalala road, north of the Luapula river, replacing the old temporary game reserve which lay astride the main road to Mufulira and included too many villages.

Lundazi Dam (5 square miles): an area enclosing the dam at Lundazi Boma, itself a scenic attraction and resort for wild birds and game, mostly small but now including two hippo.

Lunga (600 square miles) : an uninhabited area for general preservation, lying in the Kabompo-Lunga fork in the Mwinilunga District. 
Additionally, the provisions of the ordinance relating to game reserves were applied to the Nsefu game camp area, within the Kunda controlled area on the banks of the Luangwa in the Fort Jameson District, and to the Kafue Gorge controlled area which replaced the old Kafue Gorge and Kafue Bridge game reserves.

Broadly, it may be said that the game position is improving in the eleven reserves, covering some 10,855 square miles, none of which include settlements, and which with the 8,650 covered by the National Park comprise 19,505 square miles or just over $6 \frac{1}{2}$ per cent of the Territory's total area. This is a fair proportion even considering that much of the game reserve areas, particularly in the Luangwa Valley, are waterless and mostly valueless even for game ; future policy should be directed to improving the general plan on its present basis, consolidating areas where desirable on the principle of "give and take", rather than to acquiring further extensive areas. The weakest spots are the Lavushi Manda Reserve in the western portion of the Mpika District, surrounded by villages ; and the Mweru Marsh Reserve wherein not only the needs of locust control but also the fishing potential render long-term prospects of ensuring sanctuary conditions somewhat doubtful.

The proposal to establish a game reserve in the Luali area, a watershed zone in the east of the Kawambwa District, is still under consideration. General agreement regarding the Nyika Plateau, on the Nyasaland border in the extreme north-east of the Lundazi District and south-east of the Isoka District, was reached : desirable as was protection not only of game but also of all natural resources on this high watershed, the status of the land as a native reserve precluded for the present any form of alienation as a national park and the best compromise seemed to be to declare a controlled area and apply to it the provisions of the ordinance relating to game reserves. Implementation of this course now awaits final sanction by Government.

\section{Controlled Areas.}

The following controlled areas were declared during the year : Chisamba, Kafue Gorge, Mporokoso, Zambezi (Mantowa), Blue Lagoon.

Very few "game" areas in the Territory now remain uncontrolled. The initial object of controlling hunting from outside, and so placing responsibility for the fate of the game squarely on the inhabitants of these areas, has been achieved and it is now unfortunately obvious that the continuing de- 
terioration of game which must be reported from most controlled areas in native trust land and native reserves results from the activities of the local inhabitants. It is perhaps difficult for the average African to understand that, with increase in population and firearms, the game cannot possibly hold its own against more or less unrestricted hunting as it did in the past; but the hard fact is that unless inhabitants of the controlled areas are willing to ration or otherwise restrict themselves in the killing of game, in another ten to twenty years there will literally be nothing left outside the game reserves. Should a thriving agriculture by then have superseded wild life, the damage would be more to sentiment than economics; but having regard to the pace of rural development in even this urgent phase and the poor potential of vast areas of bush-land, it is more likely that tens of thousands of square miles will become just completely unproductive. On the more hopeful side, certain native authorities are showing a definite interest in conservation of wild life : Chief Nsefu's Game Camp is already quite famous and Chief Mwase-Lundazi wishes to follow suit. Native authorities in the Kasama, Chinsali, Mkushi and Balovale Districts have also indicated their interest in local reservations, for varying reasons, and if such interest were backed by a genuine sense of responsibility in the matter, there could be some real progress.

\section{Protection of Particular Species.}

No further protection of particular species was enacted during the year. It is too early to judge the effect of the recently introduced protection of eland, sable in the Eastern Province, and lechwe north of the Kafue River, though it may be said that the older protection of the black lechwe in the Bangweulu area is at least enabling the species to hold its own. Complaints of garden raiding by eland are not infrequently received from Africans; the eland does sometimes raid crops but, in view of the latitude allowed under the law of damage feasance, there is no reason to deprive this fine animal of its chance of survival.

The numbers of hippo in the Luangwa River form a gratifying testimony to the efficacy of their protection there. Outstanding proposals for protection of these animals elsewhere relate to the Zambezi Valley below the Falls, and the Chingola District; when these are implemented there will be few areas left where hippo are not protected. Hippo are very occasionally dangerous, often as a result of being wounded either in fights between themselves or by hunters. On the other hand there is a growing recognition of their importance in the economy of swamp and 
riverine areas : they not only keep open the channels by their traffic but also keep the waters well fertilized with their dung. It is by no means a coincidence that good hippo areas are also good fishing areas.

\title{
THE WILD LIFE SITUATION IN SOUTHERN RHODESIA, I952
}

\author{
By I. D. M.
}

It is sad to have to report that the game in Southern Rhodesia is fast disappearing and if the Government's present policy continues for much longer, it will be exterminated except in a few areas. In the past, this has happened in the Union of South Africa and now it is to repeat itself north of the Limpopo.

Generally speaking, the white population of Southern Rhodesia does not appreciate the value of wild life to the same extent as they do in East Africa. Why this is so is hard to say. Perhaps one reason is that the Europeans have never had the opportunity of seeing vast herds of game ranging the plains as can still be seen in Kenya and Tanganyika. The country in Rhodesia does not lend itself to such landscape, for the uncultivated areas are mostly bush and there are few plains bordered by mountains as there are further north. Be that as it may, the wild life is hard put to it to survive and there is even no game department to preserve where suitable, and strictly licence and control elsewhere. There are, however, some enthusiasts and the local Press gave a great deal of publicity recently to a schoolboy who advocated setting aside an area in the Zambesi valley as a game reserve. This boy had many supporters and it is hoped that his proposal will become more than an idea, but it is a regrettable fact that " mountains have to be moved unless there is money in the thing."

The wild life that remains is roughly concentrated in three areas :-

(1) In the neighbourhood of the Wankie Game Reserve on the western edge of the territory.

(2) In the south towards the Transvaal and Portuguese

East Africa border.

(3) In the Zambesi valley in the north.

Turning to these three areas, the situation to-day is briefly as follows :-

In the Wankie Game Reserve area there is still a good deal of game, thanks largely to the existence of the reserve which is so 